\title{
Effect of scrotal insulation on the pituitary-testicular axis of the ram
}

\author{
S. W. Byers* and T. D. Glover \\ Reproductive Biology Group, Department of Veterinary Anatomy, University of Queensland, \\ St Lucia, Brisbane, Queensland 4067, Australia
}

\begin{abstract}
Summary. The testes of rams were insulated for 28 days. After 28 days typical degenerative changes occurred in the tubular compartment of the testis. Spermatozoa, spermatids and, in many tubules, spermatocytes were absent. A pronounced dilatation of the testicular lymph vessels was noted, and a morphometric study indicated that the volume fraction occupied by Leydig cells was greater than in controls. A serial bleeding regimen showed that peripheral plasma concentrations of FSH were elevated and of testosterone were usually reduced after scrotal insulation. Although mean testosterone levels were unchanged after 7 days of treatment, there were more hormone episodes, each of significantly reduced amplitude. $\mathrm{LH}$ values were elevated at this time and there was an increase in the number and amplitude of LH episodes. After 14 days of scrotal insulation, mean and basal levels of testosterone were significantly reduced, and episodes of secretion were much smaller in amplitude. Mean LH values were elevated and each secretory episode was of significantly greater amplitude than in control blood. These results show that the testes of scrotally insulated rams are relatively insensitive to endogenous $\mathrm{LH}$ and that this treatment affects cells within the seminiferous tubule and those in the interstitial compartment.
\end{abstract}

\section{Introduction}

The adverse effects of elevated temperature on the function of the mammalian testis have long been recognized and even relatively modest increases in temperature are known to impair spermatogenesis (Blackshaw, 1977). The heated testis has therefore been used to investigate testicular function. The effects of high ambient temperature, local heating of the scrotum and cryptorchidism on spermatogenesis are well known and relatively consistent (VanDemark \& Free, 1970; Blackshaw, 1977). However, the effects of these treatments on the endocrine status of the testis in vivo are not as clear (Collins, Collins, McNeilly \& Tsang, 1978; Main, Davies \& Setchell, 1978; Damber, Bergh \& Janson, 1978). The purpose of the present study was to examine the effects of heat-induced testicular damage on plasma concentrations of hormones to clarify some of the relationships between gonadal hormones and the pituitary gonadotrophins. The androgenic response of heat-damaged testes in vitro is described by Byers (1984).

Several earlier investigations into the hormonal changes that accompany injury to the testes have demonstrated considerable variation in the concentrations of $\mathrm{LH}$ and testosterone (Collins $e t$ al., 1978; Main et al., 1978). Because of this variation, quite large changes in mean values obtained for these hormones are sometimes dismissed as being insignificant. Multiple blood sampling

* Present address : Department of Anatomy, Georgetown University, Medical and Dental Center, 3900 Reservoir Rd, N.W. Washington D.C. 20007, U.S.A.

(C) 1984 Journals of Reproduction \& Fertility Ltd 
techniques show that in a number of species testosterone secretion is episodic, with values fluctuating as much as 20-fold within a few hours (Bartke, Steele, Musto \& Caldwell, 1973; Katongole, Naftolin \& Short, 1971, 1974). This indicates that a true picture of changes in hormone secretion can only be obtained if a serial bleeding regimen is adopted. Furthermore it seems likely that the number and amplitude of hormone episodes as well as basal circulating levels are important. For these reasons a serial bleeding regimen was adopted in the present work, and, to minimize between-animal variation, each animal was serially bled before treatment. This bleed served as a control against which all post-treatment bleeds could be compared.

\section{Materials and Methods}

Animals and blood sampling. Mature Merino-cross rams 3-6 years of age were housed in a controlled environment ( $12 \mathrm{~h}$ light: $12 \mathrm{~h}$ dark) with an average daily temperature of $23^{\circ} \mathrm{C}$, fed a maintenance diet once daily and allowed water ad libitum. All animals were fitted with an indwelling jugular cannula (Deseret Pharmaceuticals, Sydney, Australia) and blood $(10 \mathrm{ml})$ was withdrawn into heparinized blood tubes at $1-\mathrm{h}$ intervals for $24 \mathrm{~h}$ (control bleed). Blood was centrifuged immediately and plasma stored at $-20^{\circ} \mathrm{C}$ until assayed. The animals were divided into 2 groups and scrotal packs (Glover, 1956) were fitted to the animals in one of the groups. These animals and those in the control group were each serially bled after 7,14 and 28 days of scrotal insulation.

Morphological techniques. Perfusion fixation was chosen in the present study to circumvent the problems associated with immersion fixation, i.e. mechanical damage caused by dicing unfixed tissue, the slow penetration of fixative giving rise to degenerative changes and shrinkage artefacts, and also a differential response by cells to the slow increase in fixative concentration around them (Christensen, 1970). The rate of perfusion was chosen to approximate the normal blood flow of the testicular artery in the ram (Waites $\&$ Setchell, 1964). Three rams that had been scrotally insulated for 28 days and 3 control animals were each initially anaesthetized with intravenous pentobarbitone sodium (Sagatal: May and Baker, Sydney, Australia) and maintained on halothane and oxygen. The testicular artery was located and a bevelled polyvinylchloride catheter was inserted into the artery proximal to the superior and inferior epididymal arteries. Before in-situ perfusion the artery was ligated immediately above the catheter. Heparinized saline $(9 \mathrm{~g} \mathrm{NaCl} / \mathrm{l})$ was perfused at $4 \mathrm{ml} / \mathrm{min}$ to remove blood from the testis and the tissue was fixed, by perfusing at the same rate with $100 \mathrm{ml} 0.1 \mathrm{M}$-cacodylate buffer containing $1 \%$ paraformaldehyde, $1.5 \%$ glutaraldehyde and $0.05 \%$ calcium chloride $\mathrm{pH} 7 \cdot 2$, followed by $100 \mathrm{ml} 0 \cdot 1 \mathrm{M}$-cacodylate buffer containing 4\% paraformaldehyde and $5 \%$ glutaraldehyde. Perfusions were carried out at $25^{\circ} \mathrm{C}$. The perfused testis was removed and small pieces $\left(1 \mathrm{~mm}^{3}\right)$ were washed in cacodylate buffer and postfixed for $1 \mathrm{~h}$ in $1 \%$ osmium tetroxide. After washing in buffer the tissue was dehydrated in ethanol, cleared in 1,2-epoxypropylene and embedded in Araldite. Sections were cut at $2 \mu \mathrm{m}$, stained in toluidine blue and examined and photographed using a Zeiss photomicroscope.

Morphometry. A quantitative determination of the volume fraction of various components of testis tissue was accomplished using a 42-point graticule and the methodology of Weibel, Kistler \& Scherle (1966). The $2 \mu \mathrm{m}$ sections stained with toluidine blue were viewed at a magnification of $\times 400$. Volume fractions of seminiferous epithelium, tubular lumen, Leydig cells, lymphatic vessels, blood vessels and undefined interstitial tissue were calculated from tissue sections taken from each of 20 different blocks from each animal. At least 10000 test points/animal were counted. Leydig cells were distinguished from other interstitial cells by their prominent nuclei with distinct heterochromatin and conspicuous nucleolus and by the variable number of lipid droplets present in the cytoplasm. Lymphatic vessels were recognized by their variable outline and large lumen relative to the extremely attenuated lining endothelium. The lumen of lymphatics in perfused tissue contains a uniform grey precipitate in contrast to the clear lumina of blood vessels. 
Radioimmunoassays. Plasma concentrations of LH and FSH were measured by heterologous double-antibody systems. For the LH assay an anti-bovine antiserum (Lee et al., 1976) and an ovine tracer (Papkoff G3.222B) were used. NIH-LH-S20 was used as the standard preparation. Interand intra-assay coefficients of variation were 8.4 and $5.6 \%$ respectively while the sensitivity of the assay was $0.15 \mathrm{ng} / \mathrm{ml}$. For the FSH assay an anti-human antiserum (Butt M94) and an ovine tracer (Papkoff G4.150C) were used (McNeilly, McNeilly, Walton \& Cunningham, 1976). Inter- and intra-assay coefficients of variation were 9 and $4.4 \%$ respectively, sensitivity was $1.2 \mathrm{ng} / \mathrm{ml}$ and NIH-FSH-S12 was used as the reference standard. Testosterone concentrations were measured by the radioimmunoassay described by Byers, Dowsett \& Glover (1983). Inter- and intra-assay coefficients of variation were 5.7 and $4 \%$ respectively. The smallest amount of authentic testosterone that could be measured in $100 \mu \mathrm{l}$ charcoal-stripped wether plasma was $16 \mathrm{pg}$ and recovery of testosterone tracer from $100 \mu \mathrm{l}$ plasma was $90 \%$. Specificity, expressed as the ratio of measurements with and without separation of testosterone from $5 \alpha$-reduced androgens on Celite columns, was usually $>90 \%$.

Statistical procedures. Throughout the study, LH and testosterone were secreted in pulsatile manner and the number and amplitude of hormone episodes, basal levels and mean 24-h levels were measured. An episode was defined as an increase of $>50 \%$ between consecutive samples (Lincoln, Peet \& Cunningham, 1977). The basal level was defined as the mean of the 5 lowest values within each 24-h bleed.

Plasma FSH concentrations did not show marked episodic secretion; fluctuations rarely exceeded $30 \%$ about the mean (compared with 20 -fold variations in testosterone and LH levels), and only mean $24-\mathrm{h}$ levels were examined.

After partitioning the various measures (peak number, peak amplitude, basal levels and mean 24-h levels), data showed an approximately normal distribution, and the results were therefore analysed by simple $t$ tests. Data within groups were analysed using the paired $t$ test while data between groups were analysed by the $t$ test for 2 means. Data are expressed as percentage of the control blood value (i.e. the pre-treatment result for each animal was assigned a value of $100 \%$ and all post-insulation results were expressed as a percentage of this). All statistical analyses were carried out on untransformed data.

\section{Results}

\section{Morphology}

Characteristic differences were observed in the testes of treated and control rams. Scrotal insulation for 28 days resulted in a reduction in the types of cell found in the seminiferous epithelium and the tubules had taken on a scalloped appearance due to pronounced infoldings of the basement membrane (Pl. 1, Figs 1-4). A thickening of the lamina propria was observed and dilatation of the interstitial lymphatics was conspicuous.

Basically, 2 distinct types of tubule were seen in the testes of experimental rams. Spermatocytes and Sertoli cells were both present in type 1 tubules (Pl. 1, Fig. 3) while type 2 tubules possessed Sertoli cells and spermatogonia only (Pl. 1, Fig. 4). Lipid droplets in Sertoli cells from control rams were generally small and confined to the basal portion of the cell. In contrast, lipid droplets in type 1 and type 2 tubules were large and tended to be distributed throughout the cell.

\section{Morphometry}

The morphometric analysis showed that insulation of the scrotum gave rise to a number of quantitative changes in testis morphology (Table 1). There was a pronounced decrease in the volume fraction occupied by the seminiferous tubules as a whole, which was presumably due to a reduction in the number of germ cells. The volume fraction occupied by the interstitial tissue was 
Table 1. Volume fractions of the components of testis tissue from control and scrotally insulated rams

\begin{tabular}{lcl}
\hline & $\begin{array}{c}\text { Control rams } \\
(\mathrm{N}=3)\end{array}$ & $\begin{array}{c}\text { Treated rams } \\
(\mathrm{N}=3)\end{array}$ \\
\hline Seminiferous epithelium & $0.66 \pm 0.013$ & $0.41 \pm 0.014^{* *}$ \\
Tubular lumen & $0 \cdot 13 \pm 0.01$ & $0 \cdot 12 \pm 0 \cdot 01$ \\
Leydig cells & $0.07 \pm 0.01$ & $0 \cdot 15 \pm 0.014^{* *}$ \\
Blood vessels & $0.08 \pm 0.008$ & $0 \cdot 10 \pm 0.01$ \\
Lymphatics & $0.03 \pm 0.005$ & $0 \cdot 13 \pm 0.014^{* *}$ \\
Interstitial tissue (undefined) & $0.03 \pm 0.007$ & $0 \cdot 10 \pm 0.012^{* *}$ \\
Testis weight & $127.6 \pm 10 \cdot 2$ & $61 \cdot 3 \pm 6.4^{* *}$ \\
\hline
\end{tabular}

Values are mean \pm s.e.m.

${ }^{* *} P<0.001$ compared with control value $(t$ test).

correspondingly increased, with a marked increase in the volume occupied by lymphatic vessels. The volume fraction of Leydig cells was increased.

\section{Changes in peripheral $\mathrm{LH}$ and testosterone concentrations}

Text-fig. 1 shows 24-h testosterone and LH profiles for one ram after $0,7,14$ and 28 days of scrotal insulation. After 7 days of scrotal insulation (Text-fig. 2), mean 24-h testosterone levels were unchanged. There were, however, more testosterone episodes, each of smaller amplitude, than in the pre-insulation bleed $(P<0.05)$. Basal levels of testosterone were substantially, but not significantly, lower. Mean LH values were elevated at this time $(P<0.05)$ and there were more episodes, each of significantly greater amplitude, than in control blood $(P<0.05)$. Basal levels were unchanged.

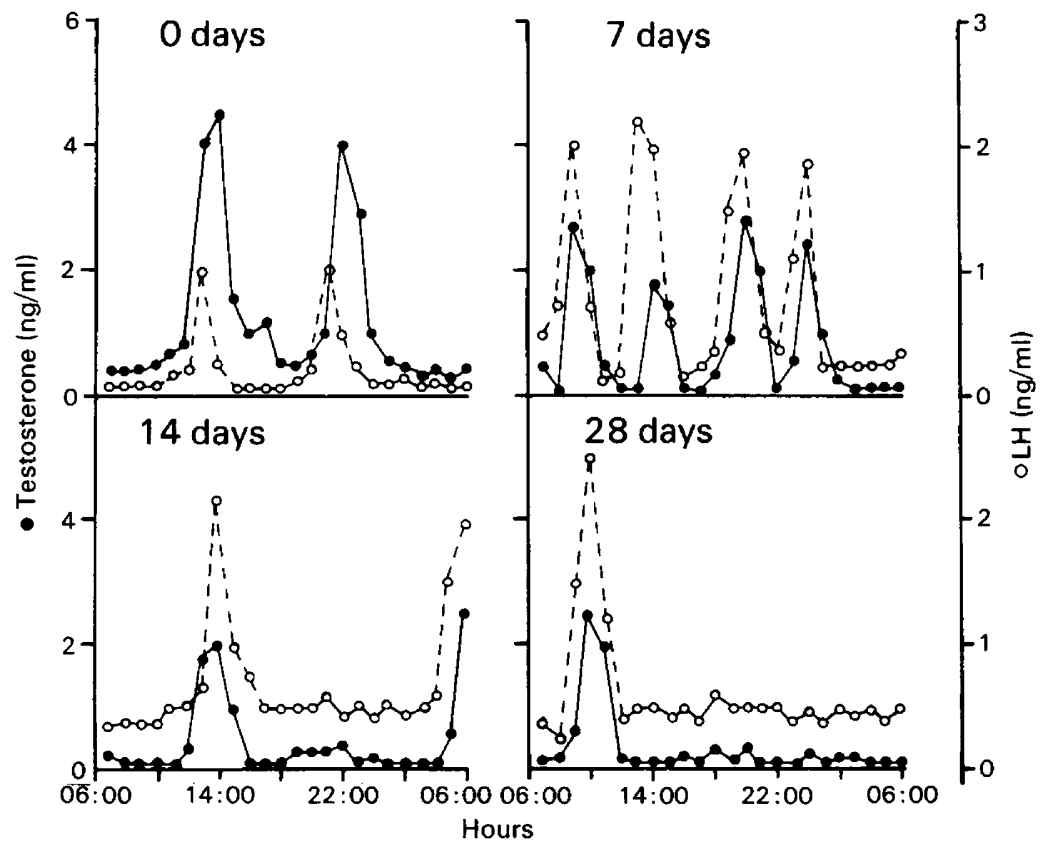

Text-fig. 1. Mean 24-h LH and testosterone profiles for 1 ram after $0,7,14$ and 28 days of scrotal insulation. 
After 14 days of scrotal insulation (Text-fig. 2), mean 24-h testosterone levels were significantly lower than the pre-treatment or control group values $(P<0.05)$. The number of testosterone episodes was not significantly different from either pre-treatment values or control animal values although these episodes were of smaller amplitude $(P<0.05)$. However, basal levels of testosterone had declined considerably and were significantly lower than levels in the control group and pretreatment bleed $(P<0.005$ and $P<0.05$ respectively). Mean $24-\mathrm{h}$ LH values were still elevated after 14 days of scrotal insulation when compared with pre-treatment values but were not significantly higher than those in the control group. Also, although the number of LH episodes had returned to control values, they were of significantly greater amplitude than those in the pretreatment blood samples. Basal levels of LH were unchanged after 14 days of scrotal insulation. After 28 days of scrotal insulation the differences between the two groups were similar to those found after 14 days and the results are not presented here.

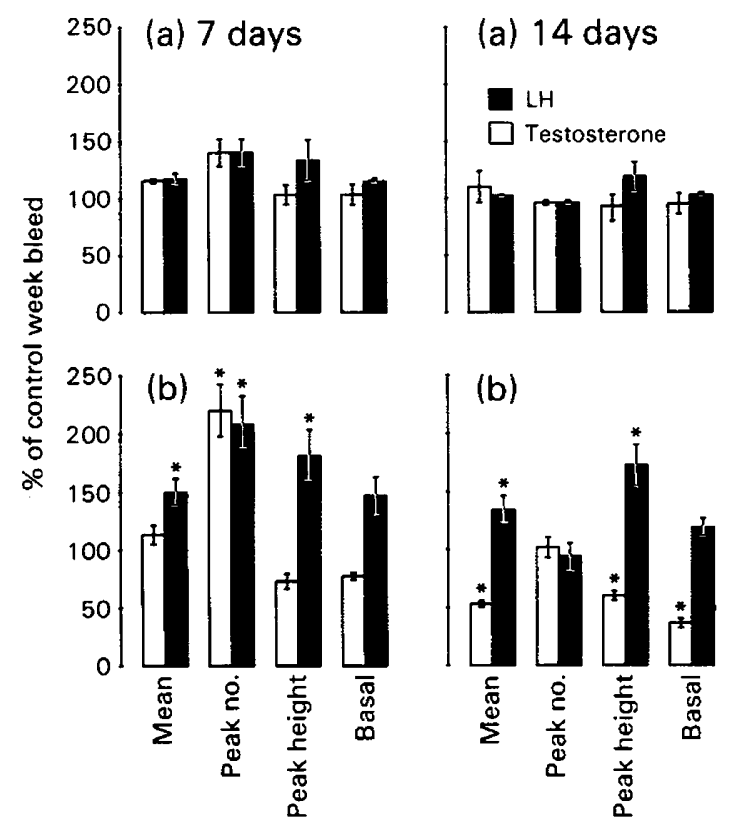

Text-fig. 2. The effect of scrotal insulation for 7 and 14 days on LH and on testosterone concentrations, mean 24-h levels, peak number and peak amplitude. Results are expressed as percentage change from control week blood for each group. Error bars indicate the s.e.m. (a) Control rams $(N=5)$. (b) Scrotally insulated rams $(N=7)$. At 7 days the untransformed data were: (a) $2 \cdot 99,0 \cdot 72,3 \cdot 2,3 \cdot 2,8 \cdot 21,1 \cdot 17,0 \cdot 72$ and $0 \cdot 71$; (b) $2 \cdot 83,1 \cdot 02,4 \cdot 0,3 \cdot 9,5 \cdot 81,1 \cdot 92,0 \cdot 74$ and $0.63 \mathrm{ng} / \mathrm{ml}$. At 14 days the untransformed data were: (a) $2 \cdot 57,0.71,2 \cdot 2,2 \cdot 2,7 \cdot 4,1 \cdot 3,0 \cdot 8,0.54$; (b) $1 \cdot 51,0.94,2 \cdot 6,2 \cdot 6,4 \cdot 9,1 \cdot 8,0 \cdot 31$ and $0.69 \mathrm{ng} / \mathrm{ml}$. * Significantly different from controls $(P<$ $0.05)$.

\section{Changes in peripheral FSH concentrations}

Mean FSH levels (Text-fig. 3) did not change after 7 days of scrotal insulation but after 14 days of treatment levels were $70 \%$ higher than in controls $(P<0.05)$. FSH levels were still elevated after 28 days of scrotal insulation $(P<0.05)$. 


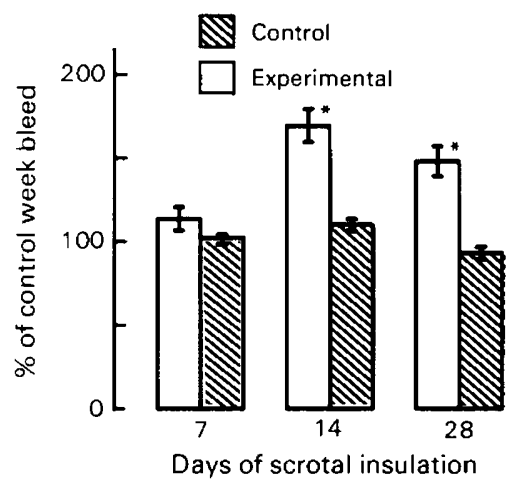

Text-fig. 3. Mean 24-h FSH concentrations, expressed as percentage of control week blood for control $(\mathrm{N}=5)$ and scrotally insulated $(\mathrm{N}=7)$ rams after 7,14 and 28 days of scrotal insulation. Error bars indicate the s.e.m. The untransformed data were $27 \cdot 1,25 \cdot 7,45 \cdot 8,27 \cdot 8$, 38.2 and $22.0 \mathrm{ng} / \mathrm{ml}$. * Significantly different from controls $(P<0.05)$.

\section{Discussion}

This study describes qualitative and quantitative changes in the testicular morphology of rams after scrotal insulation as well as changes in the endocrine status of the animals. Spermatocytes were present in some tubules but not in others, and a characteristic sloughing of the more mature spermatogenic elements was observed. After 28 days of scrotal heating, the dilatation of lymphatic vessels in the treated rams is quite spectacular, probably due to an increase in lymph flow (Cowie, Lascalles \& Wallace, 1964), shrinkage of the seminiferous tubules, or a combination of the two. A similar dilatation of the lymphatics would not be as pronounced in unperfused tissue and doubtless explains why this phenomenon has only been reported on rare occasions (Rich \& de Kretser, 1977). These changes were accompanied by an increase in the volume fraction occupied by Leydig cells. Scrotal insulation does result in a considerable decrease in testis weight (Byers, 1984) and it is possible that the apparent increase in Leydig cell volume is due largely to tubule shrinkage and the consequent aggregation of interstitial tissue into a smaller volume, as suggested by Bascom (1923) and Moore (1924) after cryptorchidism. This aggregation effect will be less pronounced in the perfused tissue used in the present study as space left after shrinkage of the seminiferous epithelium is partly accounted for by the dilated lymphatics. Kerr, Rich \& de Kretser (1979) have confirmed the impressions of earlier workers (Hanes, 1911; Lynch \& Scott, 1951), by showing, using morphometric techniques, that experimental cryptorchidism in rats results in an increase in Leydig cell size, together with a proliferation of mitochondria, Golgi membranes and smooth endoplasmic reticulum within the cells. These changes are characteristic of Leydig cell hyperstimulation and

\section{PLATE 1}

Fig. 1. Light micrograph of a normal ram testis illustrating active spermatogenesis. $\times 66$.

Fig. 2. Light micrograph of a scrotally insulated ram testis. Spermatozoa and spermatids are absent and a pronounced shrinkage of the seminiferous tubules has occurred. Lymphatic vessels (asterisk) are also dilated. $\times 66$.

Fig. 3. Type 1 tubule (see text) from a scrotally insulated ram testis. Spermatocytes (spc), Sertoli cell nuclei (n) and lipid droplets (arrowheads) are present. $\times 300$.

Fig. 4. Type 2 tubule (see text) from a scrotally insulated ram testis. Spermatocytes are absent and Sertoli cell nuclei (n) have migrated from their basal position towards the centre of the tubule. Thickening and infolding of the lamina propria is shown (arrows) $\times 300$. 
PLATE 1

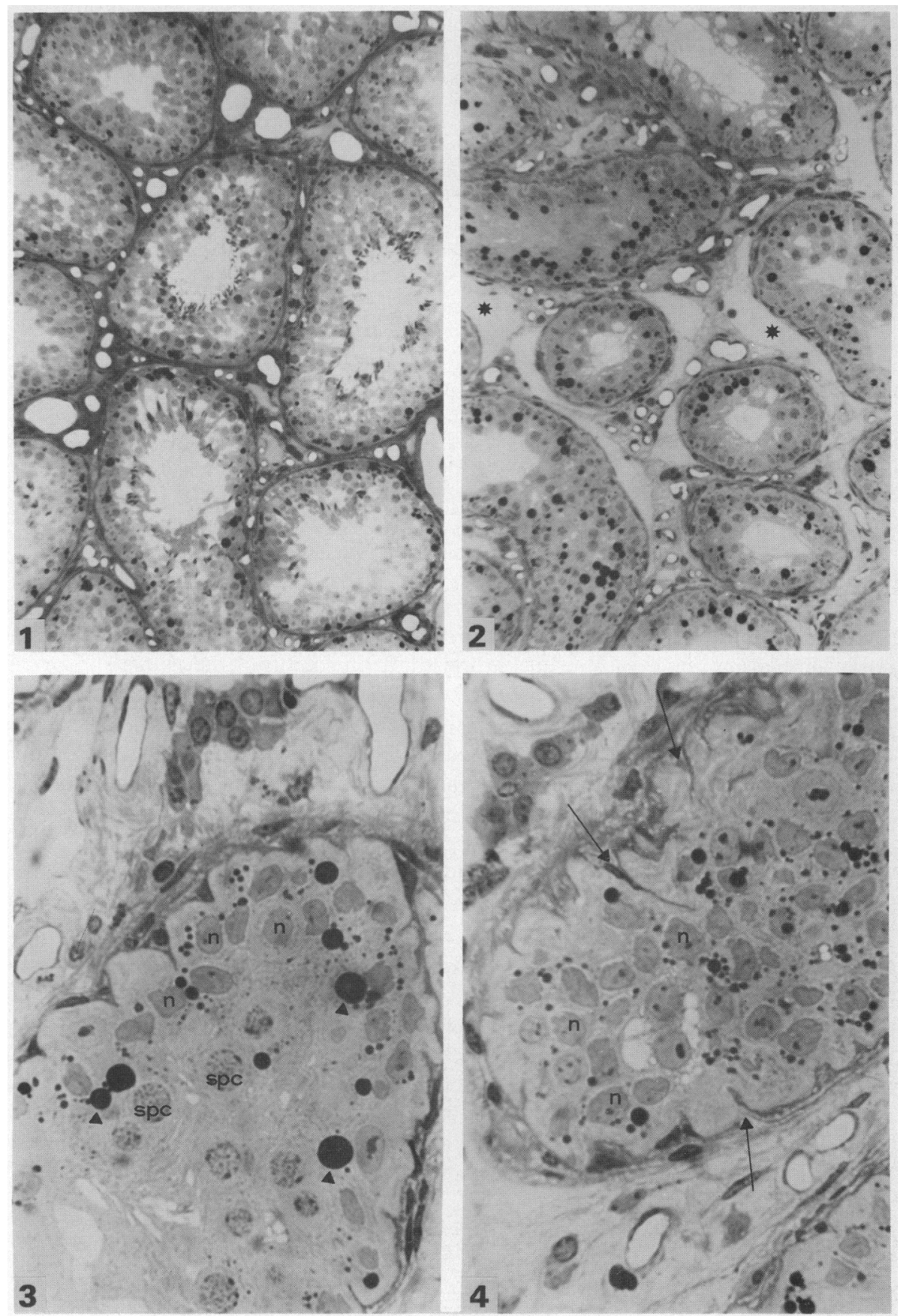


could be interpreted as a response by the Leydig cells to the elevated gonadotrophin levels that often accompany testicular damage. Leydig cell hypertrophy occurs in man after prolonged treatment with hCG (de Kretser, 1967) and, in rats, an increase in the mitotic index of Leydig cells and in Leydig cell number occur after administration of hCG (Chemes, Rivarola \& Bergada, 1976; Christensen \& Peacock, 1980). However, evidence is available to indicate that these changes may not 'be attributable to elevated LH concentrations alone, but may also be due, at least in part, to a direct response of the Leydig cells themselves to seminiferous tubule damage (Aoki \& Fawcett, 1978). Risbridger, Kerr \& de Kretser (1981) have described 'hypertrophic' Leydig cells in unilaterally cryptorchid animals and those with ligated efferent ducts, conditions in which LH levels are normal. Nevertheless, the present results show that scrotal insulation does elicit changes in the hormonal status of the animals. Mean levels of testosterone were unchanged after 1 week of treatment and although there were more testosterone episodes basal levels and peak amplitudes were substantially lower. The fact that after 1 week of treatment there were more LH episodes, each eliciting a corresponding testosterone episode, indicates that this maintenance of normal testosterone concentrations is due to a change in the pituitary secretion of LH. After 14 days of treatment, however, LH episodes were larger than normal, and although each episode stimulated the testis to produce testosterone, these testosterone episodes were of much reduced size. This indicates that the testes of experimental rams were relatively unresponsive to endogenous LH. Testosterone secretion in experimentally cryptorchid bulls and rams has also been shown to be insensitive to exogenous LH (Schanbacher, 1979a; 1980).

A rise in circulating FSH in scrotally insulated rams, accompanied as it was by a decrease in testosterone, contrasts with the results of Main et al. (1978) and Collins et al. (1978) for scrotally heated and $\mathrm{X}$-irradiated rats, in which there were no consistently significant changes in peripheral testosterone values although FSH levels increased. One explanation for this discrepancy may lie in the differences between the chronic effects of scrotal insulation and the relatively acute effects of these other forms of treatment. It is also possible that the serial bleeding regimen adopted with rams in this study may have revealed changes which were undetectable in single blood samples. In any event, increased FSH concentrations in scrotally insulated rams could be due, in part at least, to a corresponding decline in testosterone values. Immunization against testosterone results in increased secretion of FSH as well as LH (Hillier, Groom, Boyns \& Cameron, 1975) and suggests that, in physiological circumstances, testosterone might exert a negative feedback effect on FSH secretion as well as on LH (Schanbacher, 1979b; D'Occhio, Schanbacher \& Kinder, 1982). However, after 1 week of scrotal insulation changes in the relationship of testosterone to LH were observed, without a rise in FSH. This apparently separate regulation of the two gonadotrophins does imply that some selective regulation of FSH secretion exists, perhaps through tubular inhibin.

We have demonstrated that scrotal insulation not only affects cells within the seminiferous tubule but also the function of the cells in the interstitial compartment. This work shows conclusively that testosterone levels are reduced following this treatment and that this reduction can be accounted for by a reduced response of the testis (Leydig cell) to the elevated levels of endogenous LH that occur after scrotal insulation. It is equally likely however that these changes are in part secondary to seminiferous tubule damage. Although both testicular oestradiol (Catt $e t$ al., 1980) and an LHRH-like factor produced by the seminiferous tubule (Sharpe, Fraser, Cooper \& Rommerts, 1981) have been shown to exert an intratesticular control of Leydig cell steroidogenesis, the relationship between these substances and Leydig cell structure and function has not yet been investigated.

The role of the seminiferous epithelium in exerting some control of Leydig cell activity has been emphasized by Ucci (1982), who showed that there was an inverse relationship between Leydig cell size and activity, and germ cell maturation in the normal urodele testis. Within a single testis, degenerating spermatogenic elements were invariably associated with active Leydig cells whilst mature spermatogenesis was associated with small inactive Leydig cells. This apparently contradictory phenomenon deserves further investigation in mammalian species. 
This work was supported by a grant from the Ford Foundation. We thank the NIH for gifts of the pituitary gonadotrophins and Dr R. I. Cox (CSIRO, Prospect, New South Wales, Australia) for the testosterone antiserum.

\section{References}

Aoki, A. \& Fawcett, D.W. (1978) Is there a local feedback from the seminiferous tubule affecting activity of the Leydig cells? Biol. Reprod. 17, 144-158.

Bartke, A., Steele, R.E., Musto, N. \& Caldwell, B.V. (1973) Fluctuations in plasma testosterone levels in adult male rats and mice. Endocrinology 92, 12231228.

Bascom, K.F. (1923) The interstitial cells of the gonads in cattle, with special reference to their embryonic development and significance. Am. J. Anat. 31, 223259.

Blackshaw, A.W. (1977) Temperature and seasonal influences. In The Testis, Vol. 4, pp. 517-545. Eds W. D. Gomes \& A. D. Johnson. Academic Press, New York.

Byers, S.W. (1984) The effect of scrotal insulation on the ability of ram testes to produce testosterone in vitro. $J$. Reprod. Fert. 71, 17-21.

Byers, S.W., Dowsett, K.D. \& Glover, T.D. (1983) Seasonal and circadian changes of testosterone levels in the peripheral blood plasma of stallions and their relation to semen quality. J. Endocr. 99, 141-150.

Catt, K.J., Harwood, J.P., Clayton, R.M., Davies, T.F., Chan, V., Katikinemi, M., Nozu, K. \& Dufau, M. (1980) Regulation of peptide hormone receptors and gonadal steroidogenesis. Recent Progr. Horm. Res. 36, 557-622.

Chemes, H.E., Rivarola, H.A. \& Bergada, C. (1976) Effects of hCG on the interstitial cells and androgen production in the immature rat testis. J. Reprod. Fert. 46, 279-282.

Christensen, A.K. (1970) Fine structure of testicular interstitial cells in humans. In The Human Testis, pp. 5794. Eds E. Rosemberg \& C. A. Paulson. Am. Physiological Society, Washington D.C.

Christensen, A.K. \& Peacock, K.C. (1980) Increase in Leydig cell number in testes of adult rats treated chronically with an excess of human chorionic gonadotropin. Biol. Reprod. 22, 383-391.

Collins, P.M., Collins, W.P., McNeilly, A.S. \& Tsang, W.N. (1978) Plasma FSH, LH and testosterone levels in the male rat during degeneration of the germinal epithelium caused by severe heat treatment or ligation of the vasa efferentia. J. Reprod. Fert. 54, 285291.

Cowie, A.T., Lascalles, A.K. \& Wallace, J.C. (1964) Flow and protein content of testicular lymph in conscious rams. J. Physiol., Lond. 171, 176-187.

Damber, J.E., Bergh, A. \& Janson, P.O. (1978) Testicular blood flow and testosterone concentrations in the spermatic venous blood in rats with experimental cryptorchidism. Acta endocr., Copenh. 88, 611618.

de Kretser, D.M. (1967) Changes in the fine structure of the human testicular interstitial cells after treatment with human gonadotropins. Z. Zellforsch. mikrosk. Anat. 83, 344-358.
D'Occhio, M.J., Schanbacher, B.D. \& Kinder, D.E. (1982) Testosterone feedback on FSH secretion in male sheep. J. Reprod. Fert. 66, 699-702.

Glover, T.D. (1956) The effect of scrotal insulation and the influence of season upon fructose concentration in the semen of the ram. J. Endocr. 13, 235-242.

Hanes, F.M. (1911) The relations of the interstitial cells of Leydig to the production of an internal secretion by the mammalian testis. J. exp. Med. 13, 338-354.

Hillier, S.G., Groom, G.V., Boyns, A.R. \& Cameron, E.H.D. (1975) The active immunization of intact male rats against steroid-protein conjugates: effects on circulating hormone levels and related physiological processes. In Steroid Immunoassay, pp. 97110. Eds E. H. D. Cameron, S. G. Hillier \& K. Griffiths. Alpha Omega Publishing Ltd, Cardiff.

Katongole, C.B., Naftolin, F. \& Short, R.V. (1971) Relationship between blood levels of luteinizing hormone and testosterone in bulls and the effect of sexual stimulation. J. Endocr. 50, 457-466.

Katongole, C.B., Naftolin, F. \& Short, R.V. (1974) Seasonal variations in blood luteinizing hormone and testosterone levels in rams. J. Endocr. 60, 101-106.

Kerr, J.B., Rich, K.A. \& de Kretser, D.M. (1979) Alterations of the fine structure and androgen secretion of the interstitial cells in the experimentally cryptorchid rat testis. Biol. Reprod. 20, 409-422.

Lee, V.W.K., Cumming, I.A., de Kretser, D.M., Findlay, J.K., Hudson, B. \& Keogh, E.J. (1976) Regulation of gonadotrophin secretion in rams from birth to sexual maturity. 1. Plasma LH, FSH and testosterone levels. J. Reprod. Fert. 46, 1-6.

Lincoln, G.A., Peet, M.J. \& Cunningham, R.A. (1977) Seasonal and circadian changes in the episodic release of follicle stimulating hormone, luteinizing hormone and testosterone in rams exposed to artificial photoperiods. J. Endocr. 72, 337-349.

Lynch, K.M. \& Scott, W.W. (1951) Lipid distribution of the Sertoli cell and Leydig cell of the rat testis as related to alterations in the pituitary-gonad system. Endocrinology 49, 8-14.

Main, S.J., Davies, R.V. \& Setchell, B.P. (1978) Feedback control by the testis of gonadotrophin secretion: an examination of the inhibin hypothesis. J. Endocr. 79, 255-270.

McNeilly, J.R., McNeilly, A.S., Walton, J.S. \& Cunningham, F.J. (1976) Development and application of a heterologous radioimmunoassay for ovine follicle stimulating hormone. J. Endocr. 70, 69-79.

Moore, C.R. (1924) Properties of the gonads as controllers of somatic and physical characteristics. VI. Testicular reactions to experimental cryptorchidism. $\mathbf{A m}$. J. Anat. 34, 269-336.

Rich, K.A. \& de Kretser, D.M. (1977) Effect of differing degrees of destruction of the rat seminiferous epithelium on levels of serum FSH and androgen binding protein. Endocrinology 101, 959-968. 
Risbridger, G.P., Kerr, J.B. \& de Kretser, D.M. (1981) Evaluation of Leydig cell function and gonadotropin binding in unilateral and bilateral cryptorchidism: evidence for local control of Leydig cell function by the seminiferous tubule. Biol. Reprod. 24, 534-540.

Schanbacher, B.D. (1979a) Testosterone secretion in cryptorchid and intact bulls injected with gonadotropin releasing hormone and luteinizing hormone. Endocrinology 104, 360-364.

Schanbacher, B.D. (1979b) The regulation of FSH secretion in rams. J. Reprod. Fert., Suppl. 26, 15-16.

Schanbacher, B.D. (1980) Androgen response of cryptorchid and intact rams to ovine LH. J. Reprod. Fert. 59, 151-154.

Sharpe, R.M., Fraser, H.M., Cooper, J. \& Rommerts, F.F.G. (1981) Sertoli-Leydig cell cummunication via an LHRH-like factor. Nature, Lond. 290, 785-787.
Ucci, A.A. (1982) A fine structural study of interstitial ceil changes in the testes of Necturus maculosus during a portion of the annual cycle and possible evidence for local feedback control by the seminiferous epithelium. Am. J. Anat. 165, 27-38.

VanDemark, N.L. \& Free, M.J. (1970) Temperature effects. In The Testis, vol. 3, pp. 233-312. Eds A. D. Johnson, W. R. Gomes \& N. L. VanDemark. Academic Press, New York.

Waites, G.M.H. \& Setchell, B.P. (1964) Effect of local heating on blood flow and metabolism of the testes of the conscious ram. J. Reprod. Fert. 8, 337-349.

Weibel, E.R., Kistler, G.S. \& Scherle, W.F. (1966) Practical stereological methods for morphometric cytology. J. Cell Biol. 30, 23-38.

Received 6 June 1983 